\title{
NILAI KEARIFAN LOKAL DALAM TUNJUK AJAR MELAYU KARYA TENAS EFFENDI
}

\author{
Marlina \\ Balai Bahasa Riau \\ emial: marlinabbpku@gmail.com
}

\begin{abstract}
(Title: The Value of Local Wisdom in “Tunjuk Ajar Melayu” by Tenas Effendi). This study aims at determining the value of local wisdom contained in the Tunjuk Ajar Melayu (Malay Guidance of Life) by Tenas Effendi. The main problem is what the values of local wisdom contained in the Tunjuk Ajar Melayu are. This study applied descriptive qualitative method. The primary data source is the Tunjuk Ajar Melayu contained in the book "Kesantunan dan Semangat Melayu (Politeness and Spirit of Malay)" by Tenas Effendi. The result of the research shows that Tunjuk Ajar Melayu contained local wisdom values which had to be maintained and preserved by the community owners. These values are having good intentions and good character, setting oneself in the harmonious position, positioning oneself smartly in certain situation and condition, being wise in considering and tolerating, willing to sacrifice and willing to yield, having humble heart, and maintaining good relations with neighbors. One way to maintain and preserve the values of local wisdom is to include the material of the Tunjuk Ajar Melayu as one of the local content of teaching materials in schools in Riau.
\end{abstract}

Keywords: Malay guidance of life, values, local wisdom

\section{PENDAHULUAN}

Kemajuan teknologi dan arus globalisasi mengakibatkan terjadinya krisis sosial. Krisis sosial telah menyebabkan manusia mengalami persaingan yang tidak sehat, korupsi, perang saudara, kemerosotan moral, dan terjadinya berbagai tindak kekerasan. Akibat langsung yang ditimbulkan adalah hilangnya nilai-nilai kemanusiaan, sehingga manusia pada gilirannya akan kehilangan akar tradisinya, bahkan identitas dirinya.

Arus modernisasi telah menyebabkan masyarakat terutama remaja mulai meninggalkan budaya lokal dan beralih ke budaya luar yang dianggap lebih mewakili diri mereka. Hal ini tentu berdampak pada perubahan gaya hidup dan pola pikir mereka sebagai seorang remaja. Muara dari semuanya adalah menurunnya kualitas moral para remaja.

Penurunan moral tersebut dapat dilihat dari meningkatnya angka kriminalitas di kalangan remaja, pemakaian narkoba yang telah sampai ke sekolah-sekolah, pergaulan bebas, pelecehan seksual, penganiayaan guru, hingga terjadinya pembunuhan di kalangan sesama remaja. Fenomena-fenomena ini tentu saja sangat memperihatinkan, mengingat bangsa Indonesia adalah bangsa yang beradab, beretika dan berbudi pekerti luhur.

Bangsa Indonesia sejatinya memiliki nilai-nilai karakter yang tercermin dari tradisi dan adat istiadat yang dimiliki oleh masyarakatnya. Nilai-nilai karakter inilah yang menjadi landasan moral dan menjadi pedoman hidup bagi masyarakat setempat. Nilai-nilai kehidupan inilah yang selanjutnya berkembang di dalam masyarakat dan dikenal sebagai sebuah kearifan lokal (Aji, 2019:2).

Oleh sebab itulah, nilai-nilai kearifan lokal ini harus kembali dihidupkan di kalangan remaja. Remaja dan generasi muda harus mengenal budaya dan tradisi yang ada di daerahnya. Seperti halnya dengan budaya Melayu. Budaya Melayu merupakan sebuah budaya yang sangat menjunjung tinggi nilai kesopansantunan, yang menjadi salah satu asas jati diri kemelayuan yang terpuji. Di dalam pergaulan sehari-hari sopan santun menjadi salah satu tolak ukur untuk menilai seseorang. 
Pentingnya kesopansantunan di dalam kehidupan orang-orang Melayu, menyebabkan mereka berusaha sepenuh daya dan upaya untuk menjadikan dirinya orang yang berbudi pekerti terpuji, berakhlak mulia dengan landasan iman dan takwa.

Berpegang kepada asas hidup dan menjunjung tinggi kesantunan menyebabkan orang Melayu ternama bukan hanya karena kekayaan alamnya yang melimpah, tetapi dikenal dan dihormati karena kesopan santunan, keterbukaan dan keramah-tamahannya. Itulah sebabnya nilai-nilai kesantunan diajarkan sejak dini, ditanamkan ke dalam hati anakanak mereka agar besarnya menjadi orang, yaitu menjadi orang yang santun, berbudi luhur, berakhlak mulia, elok lahirnya dan baik batinnya.

Di dalam kehidupan, manusia tidak dapat melepaskan dirinya dari kehidupan berumah tangga, bermasyarakat, berbangsa dan bernegara. Kehidupan itu memerlukan pergaulan, baik dalam ruang lingkup terbatas maupun terbuka dan luas. Karenanya, budaya Melayu memberikan tunjuk ajar tentang pergaulan itu, terutama dalam pergaulan bermasyarakat yang melibatkan banyak orang, suku dan bangsa. Orang tua-tua Melayu dengan segala kearifan dan kebijaksanaanya, telah berhasil menghimpun, menapis, mengayak dan membakukan nilai-nilai luhur yang mereka miliki, terutama dari sumber utamanya, yakni ajaran Islam. Nilai-nilai ini yang dilengkapkan dengan nilai-nilai budaya mereka yang Islami, dituangkan ke dalam bentuk tunjuk ajar, yang kemudian diwariskan secara turun temurun. Dengan nilai-nilai inilah mereka mampu mewujudkan kedamaian dan kesejahteraan dan kehidupan berumah tangga, bermasyarakat, berbangsa dan bernegara.

Tunjuk ajar Melayu mengandung berbagai nilai-nilai luhur yang dijadikan pedoman dan bekal hidup, terutama nilai-nilai luhur agama dan budaya yang islami. Nilai-nilai yang terdapat di dalam tunjuk ajar Melayu telah berurat berakar dalam kehidupan masyarakat Melayu pada zaman dahulu sehingga bisa dikatakan telah menjadi tradisi yang menaungi kehidupan masyarakatnya.
Di dalam kondisi yang benar dan konstruktif, nilai-nilai tradisi dapat membantu dinamika kehidupan masyarakat tempat nilainilai mendasar itu hidup dan berkembang, menumbuhkan dan mengembangkan integritas masyarakat, menciptakan solidaritas sosial, menumbuhkan kebanggaan akan identitas kelompok, dan berguna pula untuk mengukuhkan keharmonisan komunal. Oleh sebab itu, pada hakikatnya setiap masyarakat, baik masyarakat tradisionalmaupun masyarakat modern memerlukan nilai-nilai kehidupan yang didasari keyakinan atau kepercayaan atas hal-hal tertentu untuk mejalani perikehidupan bersama yang harmonis (WS, 2015: 199).

Nilai-nilai tradisi masyarakat Melayu ini disebut juga dengan nilai kearifan lokal. Kearifan lokal merupakan sebuah pengetahuan hasil proses adptasi komunikasi lokal dalam pengalaman hidupnya yang ditransformasikan secara turun temurun, dari satu generasi ke generasi berikutnya. Nilai kearifan lokal ini digunakan oleh masyarakat setempat dalam proses interaksi sosial kehidupan sehari-hari dengan alam dan lingkungan sosialnya sebagai bagian dari mekanisme untuk bertahan hidup (Fawziah, 2017: 96).

Kearifan lokal ini menyatu dalam sistem norma dan budaya yang diekspresikan dalam sistem budaya dan sistem sosialnya dan ditransmisikan melalui berbagai cerita-cerita berupa mitos, legenda, babad, suluk, tembang, hikayat, lontarak, dan lain sebagainya. Pada masyarakat Melayu Riau, salah satunya terdapat di dalam Tunjuk Ajar Melayu. Tunjuk Ajar Melayu ini dibukukan oleh Bapak Tenas Effendy di dalam buku yang berjudul "Kesantunan dan Semangat Melayu". Buku ini memberikan rambu-rambu tentang bagaimana seharusnya seorang anak Melayu bersikap dan berbuat di tengah-tengah masyarakat.

Nilai adalah segala sesuatu yang menarik bagi manusia sebagai subjek. Menurut Ridzal dalam (Herlina, 2014: 203), nilai adalah perasaan tentang apa yang diinginkan, ataupun apa saja yang boleh dan tidak boleh. Sedangkan menurut Bertends dalam (Herlina, 2014: 203), nilai merupakan sesuatu yang menarik bagi kita, sesuatu yang kita cari, sesuatu yang menyenangkan, sesuatu yang disukai dan 
diinginkan, atau bisa dikatakan sebagai sesuatu yang baik.

Kearifan lokal berasal dari dua kata, kearifan dan lokal. Kearifan (wisdom) bermakna pengetahuan yang berkenaan dengan penyelesaian suatu masalah untuk mewujudkan keseimbangan lingkungan dan keserasian sosial. Sedangkan istilah lokal berarti setempat (kawasan provinsi, kabupaten atau desa). Ketika berbicara tentang kearifan lokal yang akan terlintas di pikiran kita adalah sesuatu yang bersifat kelokalan/kedaerahan yang berasal dari zaman dahulu kala atau bisa juga dikatakan sebagai sesuatu warisan dari nenek moyang (Fawziah, 2017: 98).

Kearifan lokal merupakan gagasangagasan atau nilai-nilai, pandangan-pandangan setempat yang bersifat bijaksana, penuh kearifan, bernilai baik yang tertanam dan diikuti oleh anggota masyarakatnya. Untuk mengetahui suatu kearifan lokal di suatu wilayah maka kita harus memahami nilai-nilai budaya yang baik yang ada di dalam wilayah tersebut. Nilai kearifan lokal ini sebenarnya sudah diajarkan secara turun temurun oleh orang tua kepada anak-anaknya. Budaya gotong royong, saling menghormati dan tepa selera merupakan contoh kecil dari nilai kearifan lokal (Herlina, 2014: 203).

Menurut (Saddhono, 2017: 9) kearifan lokal dimaknai sebagai sebuah "perangkat" pengetahuan dan praktik-praktik yang dapat digunakan untuk menyelesaikan persoalan yang dihadapi dengan cara yang baik dan benar menurut masyarakat. Kearifan lokal merupakan sistem pengetahuan lokal yang dimiliki oleh masyarakat berdasarkan pengalaman dan petunjuk leluhurnya secara turun temurun, bersifat lentur untuk mengatasi situasi dan kondisi setempat terangkum dalam ekspresi verbal dan non-verbal untuk memperoleh ketenangan hidup bersama, manusiawi dan bermartabat. Pokok pikiran kearifan lokal meliputi ciri-ciri budaya, sekelompok manusia sebagai pemilik budaya, dan pengalaman hidup yang menghasilkan ciri-ciri budaya tersebut (Rahyono dalam Saddhono, 2017: 10).

Kearifan lokal memiliki ketahanan terhadap unsur-unsur yang datang dari luar dan mampu berkembang untuk masa-masa yang akan datang. Ketahanan kepribadian masyarakat dapat ditentukan oleh kekuatan kearifan lokal dalam menghadapi kekuatan dari luar, karena memiliki berbagai faktor strategis, yaitu pembentuk identitas sejak lahir, bukan keasingan bagi pemiliknya emosional masyarakat kuat kuat dalam penghayatan kearifan lokal, pembelajaran kearifan lokal tidak memerlukan pemaksaan, kearifan lokal mampu menumbuhkan harga diri dan percaya diri, kearifan lokal mampu meningkatkan masrtabat bangsa dan Negara (Saddhono, 2017: 10).

Kearifan lokal sebenarnya sangat berhubungan erat dengan kehidupan yang dijalani oleh manusia. Di mana kearifan lokal bisa tumbuh dan berkembang jika kehidupan manusia tetap berlangsung dan berjalan sebagaimana mestinya. Kearifan lokal bisa terus eksis di tengah dunia global jika manusia bisa menjaga budaya lokal dengan baik dan benar. Salah satu cara menjaga untuk menjaga kearifan lokal itu adalah melalui bahasa dan sastra (Disi, 2018: 5).

Sementara menurut Sultoni (2015: 231), kearifan lokal merupakan bentuk dialektika antara manusia dengan pengetahuan kehidupan. Pengetahuan yang diambil dari kehidupan di mana manusia itu berada kemudian direfleksikan untuk membantu manusia memaknai kehidupan. Sebagai pedoman masyarakat, selanjutnya kearifan lokal memberi panduan yang jelas ranahranah yang dapat dijangkau oleh tingkah laku manusia. Dalam proses terbentuknya, kearifan lokal tidak dikonsepsikan secara individu namun membutuhkan peran komunal yakni masyarakat. Selanjutnya kearifan lokal menjadi bagian dari budaya untuk kemudian menjadi identitas bahkan karakter suatu masyarakat. Karenanya, antara kearifan lokal dan budaya merupakan hubungan antara anak dengan induknya. Kearifan lokal tidak lain adalah bagian dari budaya suatu daerah.

Berdasarkan sifatnya, kearifan lokal dibedakan menjadi (a) verbal yang tercermin dalam kata-kata, klausa dan kalimat yang bersifat metaforis, dan (b) non-verbal yang tercermin dalam bahasa tubuh, berbagai simbol, lambang, gambar, dan sebagainya. Kearifan 
lokal dalam tunjuk ajar Melayu yang berupa kata-kata (verbal) yang mengilustrasikan cara yang ditempuh untuk mengatasi masalah hidup dapat bersifat biasa maupun metaforis. Oleh sebab itu, inti konteksnya

Nilai kearifan lokal dapat dimanfaatkan untuk menunjang pendidikan karakter karena dalam konsep kearifan lokal yang dimaksud dalam penelitian ini adalah segala nilai, baik nilai moral, nilai agama, nilai budaya dan nilainilai yang terdapat di dalam masyarakat yang diungkapkan di dalam Tunjuk Ajar Melayu karya Tennas Efendi.

Tennas Effendy (2006:2) mengungkapkan bahwa orang tua-orang tua Melayu mengingatkan, sebaik-baik manusia adalah mereka yang memiliki keseimbangan antara pengetahuan dan keimanan. Manusia yang memiliki keseimbangan ini lazim disebut manusia "sempurna" atau "orang bertuah" yang menjadi idaman setiap orang Melayu. Untuk mewujudkan manusia bertuah itu, orang Melayu mewariskan Tunjuk Ajar yang sarat dengan nilai-nilai luhur agama, budaya, dan norma-norma sosial.

Tunjuk ajar Melayu memiliki pengertian yaitu segala jenis petuah, petunjuk, nasihat, amanah, pengajaran dan contoh teladan yang bermanfaat bagi kehidupan manusia dalam arti luas. Menurut orang tua-orang tua Melayu, tunjuk ajar adalah segala petuah, amanah, suri tauladan, dan nasihat yang membawa manusia ke jalan yang lurus dan diridhoi Allah, yang berkahnya menyelamatkan manusia dalam kehidupan di dunia dan akhirat (Tennas Effendy, 2006).

Kedudukan Tunjuk Ajar Melayu sangat penting bagi orang Melayu karena kandungannya mencerminkan nilai-nilai luhur yang bisa dijadikan sebagai pedoman hidup dalam kehidupan sehari-hari. Tunjuk Ajar Melayu disampaikan kepada setiap generasi agar kehidupan masyarakat yang ada di bumi Melayu ini lebih terarah kepada kehidupan yang lebih baik. Pesan moral yang terdapat di dalam Tunjuk Ajar Melayu meliputi berbagai aspek kehidupan manusia seperti pesan kepada guru, orang tua, anak-anak, lingkungan, masyarakat, dan pemimpin. Pesan-pesan moral yang terkandung di dalam Tunjuk Ajar Melayu pada umumnya bersumber dari nilai-nilai dan syariat Islam. Hal ini menunjukkan bahwa orang Melayu memang dekat dengan islam. Segala sendi kehidupan masyarakat Melayu selalu mengacu kepada ajaran Islam.

Penelitian tentang Tunjuk Ajar Melayu telah banyak dilakukan oleh peneliti terdahulu. Di antaranya adalah "Analisis Nilai-Nilai Pendidikan Karakter dalam Buku Tunjuk Ajar Melayu Karya Tenas Effendy" (Raihaninur, 2019: 1-14). Penelitian ini menghasilkan kesimpulan bahwa buku Tunjuk Ajar Melayu mengandungdelapanbutirnilai-nilaipendidikan karakter yang dapat dijadikan sebagai acuan dalam pendidikan karakter di sekolah-sekolah. Nilai-niai pendidikan karakter tersebut adalah: religius, jujur, tanggung jawab, mandiri, kerja keras, peduli sosial, peduli lingkungan dan sahabat/komunikasi.

Masih menurut (Raihaninur, 2019: 13), dari ke 8 nilai-nilai pendidikan karakter tersebut, nilai religius merupakan nilai terbanyak yang terdapat di dalam Tunjuk Ajar Melayu. Hal disebabkan karena Melayu sangat erat kaitannya dengan agama Islam. Kehidupan masyarakat Melayu adalah kehidupan yang selalu berlandaskan kepada agama Islam.

Pada penelitian ini, penulis tertarik untuk mengangkat "Nilai Kearifan Lokal dalam Tunjuk Ajar Melayu" karya Tenas Effendi (Effendy, 2012). Penelitian difokuskan pada Kesantunan dalam Pergaulan. Penelitian ini dirasakan perlu karena saat ini Tunjuk Ajar Melayu sudah mulai diabaikan oleh masyarakat Melayu Riau. Hal ini disebabkan oleh kemajuan zaman dan pengaruh budaya luar yang begitu hebat menggempur budaya lokal. Akibatnya Tunjuk Ajar Melayu seolaholah hanya butir-butir kalimat yang terukir di dalam bukunya tanpa dihayati dan diamalkan lagi oleh masyarakat pemiliknya.

Oleh sebab itulah, penelitian tentang Tunjuk Ajar Melayu ini perlu dilakukan agar kembali menghidupkan ruh dan nilai-nilai yang terkandung di dalam Tunjuk Ajar Melayu. Tunjuk Ajar Melayu perlu dilestarikan karena Tunjuk Ajar Melayu memiliki banyak manfaat bagi masyarakat, yakni sebagai filter untuk menangkal arus globalisasi yang memporak porandakan mentalitas masyarakat dan 
berusaha memisahkan masyarakat dari nilainilai agama serta budaya.

Tunjuk Ajar Melayu dalam konteks menangkal budaya asing sangat terasa manfaatnya karena perbedaan tradisi antara budaya asing dengan budaya lokal. Budaya asing yang tidak kontekstual dengan adat dan tradisi kemelayuan, dapat dengan mudah diakses melalui berbagai teknologi informasi yang tersedia di mana pun, mulai dari ponsel, televisi, warnet, dan sebagainya.

\section{METODE}

Metode yang digunakan dalam penelitian ini adalah metode deskriptif kualitatif. Ratna (2012: 47) mengemukakan bahwa penelitian kualitatif memberikan perhatian terhadap data alamiah, data dalam hubungannya dengan konteks keberadaannya. Metode kualitatif melibatkan sejumlah besar gejala sosial yang relevan. Sesuai dengan namanya, penelitian kualitatifmempertahankan nilai-nilai. Sementara untuk sumber datanya adalah karya, naskah, data penelitian dan data formalnya adalah kata-kata, kalimat dan wacana.

Masih menurut Ratna (2012: 47-48), ciri terpenting metode kualitatif adalah: (1) Memberikan perhatian utama pada makna dan pesan, sesuai dengan hakikat objek, yakni sebagai studi kultural; (2) Lebih mengutamakan proses dibandingkan dengan hasil penelitian sehingga makna selalu berubah; (3) Tidak ada jarak antara subjek peneliti dengan objek peneliti, subjek peneliti sebagai instrumen utama, sehingga terjadi interaksi langsung antara keduanya; (4) Desain dan kerangka penelitian bersifat sementara sebab penelitian bersifat terbuka; (5) Penelitian bersifat alamiah, terjadi dalam konteks sosial budaya masingmasing.

\section{HASIL DAN PEMBAHASAN}

Masyarakat Melayu adalah masyarakat majemuk dengan kebudayaannya yang majemuk juga. Masyarakat Melayu memiliki budaya terbuka sehingga bumi Melayu ramai dikunjungi orang, sebagian menetap dan berbaur ataupun menyatu dengan orang
Melayu. Lambat laun. Terwujudlah masyarakat yang berasal dari berbagai kaum, suku, dan bangsa dengan latar budaya yang berbeda-beda. Untuk menyatukannya, diperlukan persamaan pandangan agar kemajemukan tersebut tidak menimbulkan perpecahan, bahkan sebaliknya bisa mendatangkan kerukunan dan kesejahteraan.

Salah satu alat pemersatu kemajemukan adalah melalui kesantunan. Sebab kesantunan dapat menimbulkan rasa saling hormat menghormati, harga menghargai, yang akan menghadirkan rasa kebersamaan dan persamaan. Puncaknya adalah terwujudnya rasa "senasib sepenanggungan, seaib dan semalu". Perpaduan inilah yang menjadi harapan setiap orang Melayu sehingga perbedaan latar suku dan budaya menyatu dalam kebersamaan yang rukun dan damai (Effendi, 2012: 85).

Tunjuk Ajar Melayu mengingatkan bahwa pergaulan hakikatnya untuk mewujudkan hubungan baik antara sesama manusia, membangun silaturrahim yang saling hormat menghormati, harga menghargai, kasih mengasihi, sehingga lahirlah masyarakat dan bangsa yang aman dan damai dan rasa kekeluargaan yang padu. Beberapa nilai kearifan lokal yang terdapat di dalam Tunjuk Ajar Melayu diuraikan sebagai berikut.

\section{Niat yang Lurus dan Sifat yang Elok Adat orang dalam bergaul Hatinya bersih berpalut iman Duduk beramai perangainya sopan Di sanalah banyak beroleh teman}

Pergaulan yang baik harus dilandasi niat yang baik juga. Niat yang baik berpangkal pada hati, jika hati bersih maka apa yang akan dilakukan juga akan menjadi bersih (baik). Hati yang bersih disebabkan karena memiliki iman yang kuat. Setelah membersihkan hati dan meluruskan niat maka bersikap dan berperilaku baik juga agar mendapatkan banyak teman. Seseorang yang memiliki sifat dan perilaku yang baik akan disenangi oleh banyak orang. Kemana pergi orang akan senang dan mau menerima dengan tangan terbuka. 
Wahai saudara dengar nasihat

Bergaul itu mencari sahabat

Kiranya jangan berniat jahat

Supaya hidup beroleh rahmat

Selain itu, dalam tunjuk ajar Melayu juga dinasihatkan agar dalam pergaulan jangan memiliki niat yang jahat kepada orang lain. Apalagi jika bersikap jahat. Niat dan sikap yang jahat akan membuat hidup tidak baik. Jika ingin hidup berkah dan mendapatkan rahmat, maka selalulah berbuat baik kepada orangorang di sekeliling kita. Sebab dalam ajaran agama, apa yang kita lakukan pada orang lain, semua itu akan berbalik kepada kita. Jika kita berbuat jahat, maka hal buruk juga yang akan menimpa kita. Sebaliknya jika kita melakukan hal-hal baik kepada orang lain, maka kebaikan juga yang akan kepada kita.

Bergaul jangan sampai mencari musuh. Cara agar bisa diterima dalam pergaulan dan mendapatkan teman adalah dengan selalu bersikap sopan dan santun. Sikap sopan dan santun akan mendatangkan rasa senang dan simpati dari orang-orang di sekeliling kita. Dengan sikap sopan dan santun juga, seseorang akan menjadi mulia.

\section{Wahai segala kaum kerabat \\ Bergaul itu luruskan niat \\ Jagalah diri pelihara tabi'at \\ Kemana pergi banyak sahabat}

\section{Tempatkan Diri pada yang Serasi}

Adat bergaul pada yang ramai

Tempatkan diri pada yang sesuai

Adat dijunjung lembaga dipakai

Supaya Nampak elok perangai

Adat bergaul dalam masyarakat

Tempatkan diri pada yang tepat

Arif membaca tanda isyarat

Bijak menengok kemahuan ummat

Supaya langkah tidak terdedat

Supaya pergaulan membawa manfaat

Agar dapat diterima di dalam pergaulan, seseorang harus bisa menempatkan diri dengan baik. Selain itu, jika ingin hubungan dengan orang sekitar menjadi baik dan harmonis, kita juga harus memperhatikan budaya dan adat istiadat yang ada di daerah Melayu. Dengan menjunjung adat istiadat yang ada di negeri Melayu ini maka secara tidak langsung hal itu akan menuntun sikap dan perilaku seseorang dalam bergaul. Sikap dan perilakunya akan menjadi elok. Dengan kata lain, adat istiadat bisa menuntun bisa menuntun masyarakat pemiliknya menjadi pribadi yang baik dan berakhlak yang mulia.

Hal lain yang juga perlu diperhatikan dalam bergaul adalah agar kita bisa mengerti dan memahami sikap dan perilaku orang-orang di sekitar kita. Apa yang mereka inginkan dan apa yang tidak mereka inginkan. Jika seseorang bisa memahami kehendak orangorang di sekitarnya, maka pergaulan akan terjalin dengan harmonis. Keharmonisan dalam pergaulan akan mendatangkan hikmah dan manfaat bagi masyarakat yang ada di dalam lingkungan pergaulan tersebut.

\section{Pandai-Pandai Membawa Diri}

Pandai-pandai membawa diri maksudnya adalah bersikap dan berperilaku baik dalam pergaulan. Orang Melayu memiliki budaya yang santun dalam pergaulan dengan teman, saudara, tetangga dan orang-orang disekitarnya. Kutipan Tunjuk Ajar Melayu mengajarkan agar dalam bergaul pandaipandailah membawa diri. Seperti kutipan di bawah ini.

\section{Wahai segala sahabat handai Bergaullah dengan elok perangai Supaya hidup rukun dan damai Saudara banyak sahabatpun ramai}

Budaya Melayu mengajarkan agar dalam bergaul seseorang harus memperhatikan sifat dan sikapnya kepada orang lain. Budi yang baik dan perangai yang elok menjadi modal utama dalam menciptakan hidup damai dan rukun dalam masyarakat. Selain itu, dengan kebaikan budi dan keelokkan perangai, seseorang akan disenangi banyak orang dan akan memiliki banyak sahabat. 
Wahai saudara ingatlah pesan Niatkan bergaul mencari teman Tunjukkan sikap santun dan sopan Supaya hidup beroleh kemuliaan

\section{Wahai saudara dengar amanah Dalam bergaul peliharalah lidah Dalam berkawan jagalah tingkah Orang suka sahabat bertambah}

Amanah berikutnya adalah agar seseorang selalu menjaga ucapan yang ke luar dari mulutnya. Jangan sampai ucapan kita menyinggung perasaan orang lain. Pepatah mengatakan, lidah terkadang lebih tajam dari sebilah pedang. Disebabkan ucapan, orang bisa berkelahi dan bermusuhan. Jika ucapan tidak dijaga maka akan menimbulkan perpecahan dan kekacauan. Selain menjaga ucapan, tingkah laku juga harus dijaga agar selalu baik. Apabila ucapan dan tingkah laku telah dijaga, maka orang-orang akan menyukai kita. Kita akan memiliki banyak teman dan sahabat. Hidup akan terasa lebih bermakna jika memiliki banyak teman dan sahabat.

\section{Bila bergaul mencari musuh Rumah tangga rusak kampung pun rusuh \\ Bangsa berpecah negeri pun rubuh Marwah tercampak, martabatpun runtuh}

Apabila seseorang tidak pandai bersikap dan berperilaku yang baik dalam pergaulan, maka bisa mengakibatkan kehancuran dalam berumah tangga. Misalnya, seorang istri atau suami tidak bersikap dan berperilaku baik kepada saudara dari suami atau istri, maka timbul permusuhuhan. Berawal dari permusuhan dengan keluarga suami atau istri, rumah tangga akan terancam. Hubungan tidak baik dengan keluarga suami atau istri tentu akan berdampak tidak baik juga ke dalam rumah tangga.

Selain itu, sikap dan perilaku yang tidak baik dalam pergaulan bisa membuat rusuh kampung yang ditempati. Apabila ada orang yang tersinggung karena ucapan dan sikap seseorang, maka bisa terpicu pertikaian antara kedua orang tersebut. Pertikaian ini bisanya juga dapat memicu pertikaian yang lebih luas. Sering terjadi pertikaian dan perkelahian antar kampung hanya karena ucapan satu orang. Disebabkan rasa tersinggung lalu yang lain merasa ingin membantu atau membela, maka timbullah pertikaian dan kerusuhan.

Pesan berikutnya yang terdapat di dalam tunjuk ajar Melayu adalah agar dalam bergaul seseorang memiliki niat yang baik, yakni untuk mendapatkan teman. Jangan sampai bergaul untuk mencari musuh. Cara agar bisa diterima dalam pergaulan dan mendapatkan teman adalah dengan selalu bersikap sopan dan santun. Sikap sopan dan santun akan mendatangkan rasa senang dan simpati dari orang-orang di sekeliling kita. Dengan sikap sopan dan santun juga, seseorang akan menjadi mulia.

\section{Wahai segala kaum kerabat \\ Bergaul itu luruskan niat \\ Jagalah diri pelihara tabi'at \\ Kemana pergi banyak sahabat}

Dalam bergaul juga harus menjaga diri dan menjaga tabiat. Yakni menjaga sikap dan perilaku dengan orang-orang di sekeliling kita. Sikap dan perilaku kita jangan sampai membuat orang marah dan tersinggung. Dalam ajaran agama, semua ini disebut sebagai akhlak yang mulia. Seseorang yang memiliki akhlak mulia akan disukai oleh orang-orang di sekelilingnya dan tentu akan mendapatkan banyak teman dan sahabat.

\section{Arif Menimbang Bijak Menenggang}

Pergaulan memerlukan kearifan untuk menjaga dan menenggang perasaan orang lain, menjaga hati orang dan memahami isi hatinya. Hubungan pergaulan dengan orang lain akan berjalan dengan baik jika kita bisa menjaga perasaan orang lain agar tidak tidak tersinggung. Selain itu, hubungan dengan orang lain juga akan berlangsung dengan baik jika kita tidak membuat aib dan malu, tidak 
membangkitkan ketidaksenangan apalagi kemarahan orang lain.

\section{Adat bergaul yang kita pegang Arif menimbang bijak menenggang Bercakap jangan sembarang-barang Berbuat jangan menyinggung orang Jangan melanggar pantang dan larang Jangan berbuat sewenang-wenang Jangan mengaib memalukan orang Jangan bergaya lagak temberang Supaya bergaul semuanya senang Hidup beramai terasa lapang}

Banyak hal yang diajarkan di dalam Tunjuk Ajar Melayu. Bahwa dalam bergaul kita harus bijak menimbang dan menenggang. Kita tidak boleh berbicara sembarangan yang bisa menyinggung perasaan orang lain. Budaya Melayu sangat memperhatikan tentang hal ini, yaitu dalam menjaga perasaan orang lain.

Begitu juga dengan pantang larang. Setaip daerah di nusantara ini tentu memiliki pantang dan larang yang harus diketahui oleh masyarakatnya. Tunjuk Ajar Melayu mengingatkan agar kita, masyarakat Melayu, jangan sampai melanggar pantang larang yang terdapat di bumi Melayu. Apa yang tidak dibolehkan, jangan dilakukan. Sebab sesuatu yang telah dipantangkan atau dilarang oleh para orang tua kita dahulu tentulah karena ada alasannya.

Tunjuk Ajar Melayu juga mengajarkan agar seseorang bisa menjaga aib dan malu saudara-saudaranya. Kita dilarang untuk membuka aib orang lain. Sebab membuka aib saudara kita sama juga dengan membuka aib sendiri. Hal ini sama dengan yang diajarkan di dalam agama Islam.

Jika beberapa hal tersebut bisa dilakukan, maka kehidupan bermasyarakat akan menjadi tenang dan damai. Akan terjalin hubungan yang baik satu dengan yang lainnya. Semua akan merasa senang dan bahagia, karena tidak akan timbul masalah dalam pergaulan sehari-hari. Hidup bersama itu akan terasa indah dan lapang.
Rela Berkorban Mau Mengalah

Rela berkorban jadikan sifat

Supaya bergaul banyak sahabat

Kerugian diri jangan diingat

Supaya yang jauh menjadi dekat

Supaya yang renggang menjadi rapat

Hidup beramai manfaatnya dapat

Orang sayang banyaklah berkat

Adat bergaul mahu mengalah

Berlapang dada menjauhi masalah

Berserah diri kepada Allah

Supaya bergaul membawa berkah

Tunjuk ajar Melayu juga mengajarkan tentang adat dalam bergaul, yakni tidak menang sendiri dan mau mengalah. Hal ini sesuai dengan budaya Melayu dan juga dengan budaya bangsa Indonesia. Sebab dalam butir-butir Pancasila terdapat tentang tenggang rasa dan tepa selera. Tenggang rasa dan tepa selera akan membuat kehidupan bermasyarakat menjadi tentram dan damai. Selain itu, adab dalam bergaul adalah berlapang dada dan menjauhi masalah. Sabar dalam menghadapi persoalan kehidupan yang menimpa diri kita serta sabar dalam menghadapi sikap dan perilaku teman, sahabat, maupun sanak saudara. Sebab setiap orang memiliki sifat dan perilaku yang berbeda. Tidak tertutup kemungkinan sikap dan perilaku teman atau sahabat kita itu tidak berkenan di hati. Akan tetapi kita harus menerima sikap dan perilaku teman atau sahabat kita itu dengan sabar agar tidak timbul permasalahan dengan mereka.

Tunjuk ajar Melayu juga mengingatkan agar kita sebagai hamba Allah menyerahkan diri dan memasrahkan diri hanya kepada Allah semata. Dengan menghadirkan Allah dalam setiap urusan hidup kita, maka semua akan menjadi berkah dan bermakna. Begitu juga dalam persahabatan dan pergaulan dengan sesama manusia. Bergaul dan bersahabatlah karena Allah agar persahabatan tersebut membawa berkah.

\section{Rendahkan Hati}

Elok bergaul merendahkan hati Jauhkan sifat tinggi meninggi 


\section{Berlagak sombong jangan sekali Supaya bergaul tidak terkeji}

Hal berikutnya yang diajarkan dalam Tunjuk Ajar Melayu adalah agar dalam bergaul bisa bersikap merendahkan hati. Kita tidak boleh bersikap sombong dengan apa yang dimiliki, karena tidak ada orang yang suka dengan teman yang sombong. Akan tetapi, jika kita rendah hati, banyak orang yang akan menyukai kita. Banyak orang yang akan nyaman berteman dan bersahabat dengan kita. Oleh karena itu, sangat penting untuk menjaga hati. Agar tidak sombong dan tinggi hati. Sikap sombong merupakan penyakit yang akan mengotori pergaulan dan persahabatan.

\section{Berendah hati banyak manfaat Dalam bergaul orang kan hormat Saudara suka sahabat mendekat Hidup beramai semakin erat Manfaatnya dapat dunia akhirat}

Tunjuk Ajar Melayu mengajarkan agar kita menjadi orang yang rendah hati. Orang yang rendah hati akan disukai oleh orang lain. Orang akan lebih hormat kepada orang yang memiliki sifat rendah hati. Sebaliknya orang sangat membenci orang yang bersifat sombong dan angkuh. Jika kita rendah hati, maka akan banyak sahabat yang akan mendekat kepada kita. hubungan dengan orang-orang di sekitar akan menjadi harmonis. Allah juga sangat menyukai orang yang rendah hati. Di dalam Alquran dikatakan tidak akan masuk surga orang yang di dadanya terdapat sifat sombong. Oleh sebab itu, berhati-hatilah terhadap sifat tercela yang satu ini.

Bisa dikatakan, sifat rendah hati memiliki manfaat dunia dan akhirat. Agar kita bisa memiliki sifat rendah hati, maka janganlah merasa kita yang paling hebat. Jangan meremehkan dan menganggap rendah orang lain.

\section{Menjaga Hubungan Baik dengan Tetangga}

Tidak dapat dipungkiri, kita hidup dalam keompok-kelompok masyarakat yang disebut dengan tetangga. Tetangga merupakan orang terdekat yang selalu berhubungan dengan kita dalam kehidupan sehari-hari. Tetangga juga yang akan selalu ada jika kita memerlukan bantuan dan pertolongan. Tetangga akan menjadi orang pertama yang hadir jika kita ditimpa musibah atau kemalangan. Oleh sebab itu, kita memang dianjurkan untuk bersikap dan berhubungan baik dengan para tetangga. Seperti yang terdapat di dalam Tunjuk Ajar Melayu berikut ini.

\section{Dengan tetangga baikkan laku Sakit senang bantu membantu Tetangga datang bukakan pintu Bertegur sapa janganlah jemu}

Adab bertetangga tidak hanya diatur dalam agama, tetapi dalam budaya Melayu juga menjadi perhatian penting. Dari kutipan Tunjuk Ajar Melayu di atas, kita diharapkan untuk bersikap baik pada tetangga. Saudara terdekat adalah tetangga. Jika kita sakit atau mendapatkan kemalangan, maka yang akan lebih duluan tahu dan datang membantu tentulah tetangga di kiri dan kanan kita. Begitu juga untuk hal-hal suka ria, tetangga terdekat juga yang akan lebih duluan membantu. Oleh sebab itu, kita harus bersikap baik kepada tetangga. Susah dan senang harus saling membantu. Apabila tetangga datang bertamu ke rumah, kita harus menyambutnya dengan baik dan ramah. Jangan pernah bosan bertegur sapa dengan tetangga. Kita harus selalu menjaga silaturahmi dan hubungan baik dengan mereka.

\section{Dengan jiran beramah tamah Jangan sekali fitnah menfitnah Jangan berkira senang dan susah Salah sedikitjangan berbantah}

Selain bersikap baik dan ramah tamah kepada tetangga, hal yang paling tidak dibolehkan dalam bertetangga adalah saling menfitnah. Fitnah dan adu domba akan merusak hubungan dengan para tetangga. Oleh sebab itu, seperti yang telah diungkapkan sebelumnya, kita harus menjaga ucapan dan lisan dengan baik. Agar tidak ada yang tersinggung oleh 
ucapan kita. Sekali saja orang tersinggung oleh ucapan kita, maka akan sulit untuk mengambil hati mereka kembali. Hubungan yang terlanjur memburuk akibat ucapan yang tidak baik akan sulit diperbaiki lagi.

\section{Dengan tetangga maaf memaafkan Kesalahan kecil jangan dibesarkan Aib dan malu jangan didedahkan Kelemahan orang jangan disingkapkan}

Kehidupan bertetangga diatur dengan baik di dalam ajaran agama Islam, begitu juga di dalam adat istiadat dan budaya Melayu. Tidak bisa dipungkiri, saudara terdekat kita adalah tetangga. Ketika seseorang berada dalam kondisi senang, bahagia, sulit, menderita sakit ataupun kemalangan, tetangga terdekatlah yang lebih dulu tahu. Tetangga juga yang akan lebih dulu datang membantu. Oleh sebab itu, kita diajarkan untuk berbuat baik kepada tetangga, saling maaf memaafkan jika ada salah dan kilaf.

Satu hal yang tidak boleh dilakukan adalahsalingmembukaaibataumengungkapkan kesalahan dan kekurangan tetangga. Sebagai seorang manusia, tetangga tentu tidak luput dari kesalahan dan kekilafan. Janganlah kesalahan tetangga menjadikan alasa permusuhan dan menimbulkan benci dan dendam. Apapun kelemahantetangga sebaiknya disimpan sendiri, jangan diungkapkan kepada orang lain. Sebab Islam mengajarkan, membuka aib saudara kita sama dengan membuka aib sendiri. Sementara tetangga adalah saudara terdekat kita.

\section{Dengan tetangga berunjuk beri Jangan mementingkan diri sendiri Mana yang hilang sama dicari Mana yang susah sama disantuni}

Kutipan tunjuk ajar Melayu di atas mengingatkan agar dalam hidup bertetangga saling memberi dan menerima. Bagi siapa yang memiliki kelebihan harta, maka berbagilah dengan para tetangga. Dalam hidup bermasyarakat, kita tidak bisa mementingkan diri sendiri. Oleh karena manusia adalah makhluk sosial yang saling membutuhkan satu sama lain. Jika tetangga kesusahan, kita harus siap membantu. Sebab jika kita kesusahan tentu tetangga juga yang akan datang membantu.

\section{SIMPULAN}

Tunjuk Ajar Melayu mengandung nilai-nilai kearifan lokal negeri Melayu. Nasihat, petuah, dan budaya yang terkandung di dalamnya bisa dijadikan sebagai rambu-rambu dalam menghadapi kehidupan bermasyarakat, baik di bumi Melayu maupun di negeri orang. Oleh sebab itu, Tunjuk Ajar Melayu dapat dijadikan sebagai bahan pembelajaran bagi siswa dan pelajar di sekolah. Hal ini bisa dilakukan dengan memasukkan Tunjuk Ajar Melayu sebagai salah satu materi muatan lokal di SD, SMP dan SMA.

Berdasarkan penjabaran hasil analisis dapat disimpulkan bahwa Tunjuk Ajar Melayu yang memberikan petunjuk tentang kesantunan dalam pergaulan memiliki beberapa nilai kearifan lokal Melayu, di antaranya yaitu: 1) Luruskan niat dan elokkan sifat, 2) tempatkan diri pada yang serasi, 3) Pandai-pandai membawa diri, 4) Arif menimbang, bijak menenggang, 5) Rela berkorban dan mau mengalah, 6) Rendahkan hati, 7) Menjaga hubungan baik dengan tetangga.

Nilai kearifan lokal yang terkandung di dalam Tunjuk Ajar Melayu memberikan petunjuk kepada masyarakat Melayu dalam hal bersikap, bergaul, dan bermasyarakat. Tunjuk Ajar melayu mengajarkan tentang kesopanan, beradat, tahu malu, sadar diri, cukup ajar, berbudi pekerti, berbudi bahasa. Hal inilah yang harus diajarkan kepada anakanak semenjak mereka kecil, dengan harapan akan mereka gunakan sampai mereka dewasa, hingga akhir hayat mereka.

Penanaman nilai kesantunan ke dalam diri anak-anak tentu harus melalui proses pendidikan dan pembelajaran yang panjang yang dimulai sejak dini sampai sepanjang hayatnya. Kearifan orang Melayu untuk mengekalkan kesopan santunan, melahirkan butir-butir tunjuk ajar yang sarat makna dan dapat dijadikan pegangan dan arahan dalam mendidik dan mengajar anak-anak. 


\section{DAFTAR PUSTAKA}

Aji, M. S. (2019). Kearifan Lokal dalam Novel Dawuk Karya Mahfud Ikhwan serta Relevansinya sebagai Materi Pembelajaran Sastra di SMA. Universitas Sebelas Maret Surakarta.

Disi, L. (2018). Pembelajaran Bahasa dan Sastra Berbasis Kearifan Lokal sebagai Upaya Optimalisasi Pendidikan Karakter Menuju Dunia Global. Jurnal Pembelajaran Bahasa dan Sastra Indonesia, 8, 1-9.

Effendy, T. (2006). Tunjuk Ajar Melayu. Yogyakarta: Balai Kajian dan Pengembangan Budaya Melayu.

Effendy, T. (2012). Kesantunan dan Semangat Melayu. Malaysia: Akademi Pengajian Melayu Universiti Malaya.

Fawziah. (2017). Nilai Karakter dan Nilai Kearifan Lokal dalam Karya Sastra: Apresiasi Sastra dalam Kumpulan Cerpen Bertanya Kerbau pada Pedati. Andragogi Jurnal Diklat Teknis, V, 95-115.

Herlina. (2014). Nilai Kearifan Lokal dalam Novel Negeri Sapati Karya Laode. M. Insan Sebagai Pendukung Pelaksanaan Pendidikan Karakter. Jurnal Pendidikan Bahasa, V0l 3, 201-210.

Raihaninur, S. dkk. (2019). Analisis NilaiNilai Pendidikan Karakter dalam Buku Tunjuk Ajar Melayu Karya Tenas Effendy. JOM FKIP UNRI, Vol 6,1-14.
Saddhono, K. (2017). Membangun Kearifan Lokal Melalui Karya Sastra dan Budaya Daerah (Jawa). In Seminar Nasional Bahasa dan Budaya (hal. 8-17). Denpasar: Jurusan Pendidikan Bahasa dan Sastra Agama, Fakultas Dharma Acarya, Institut Hindu Dharma Negeri Denpasar.

Sultoni, A. (2015). Pembelajaran Sastra Berbasis Kearifan Lokal sebagai Upaya Optimalisasi Pendidikan Karakter Kebangsaan Menuju Masyarakat Ekonomi Asean (MEA). In Seminar NasionalPendidikan Bahasa Indonesia (hal. 229-236).

WS, H. (2015). Lokal dalam Tradisi Lisan Kepercayaan Rakyat Ungkapan Larangan tentang Kehamilan, Masa Bayi, dan Kanak-Kanak Masyarakat Minangkabau Wilayah Adat Luhak Nan Tigo. Kembara, Vol 1, 198-204. Diambil dari http://ejournal.umm. ac.id/index.php/kembara/index 